\title{
"To buttress the ideal of national unity": broad South Africanism and higher education in the early twentieth century
}

\author{
Bronwyn Strydom* \\ University of Pretoria
}

\begin{abstract}
Higher education and universities in South Africa underwent a period of significant development and expansion in the period following the South African War (1899 -1902). At the same time, one of the significant facets of this era was the dramatically changing nature of white identities in South Africa. A new unified white identity known as broad South Africanism was promoted in a number of quarters by the successive administrations of the Transvaal and South African Union. For the purposes of this project, institutions for higher learning were viewed by both the public and the country's authorities as critical places where the country's youth could be welded together into a new broad South African nation, learning tolerance and broad-mindedness. This article considers how these ideals were related to higher education, by looking at the official and public view of the purpose of higher education at this time. It will begin by briefly reflecting on the way these notions were evident in higher education prior to the South African War. Under each administration following the War, the perceived unifying and nationalising function of universities is then explored, paying particular attention to the relationship between broad South Africanism and aspirations regarding South African higher education.
\end{abstract}

Keywords: broad South Africanism, conciliation, higher education, universities, Smuts, white identity, Afrikaner nationalism

The period following the South African War (1899 - 1902) was one in which university institutions took root and multiplied in South Africa. Simultaneously, this period was also one in which the broad South Africanist ideal of building a new unified white South African identity enjoyed the most currency, particularly under the first three successive administrations of the Transvaal and the Union of South Africa, although with varying forms and motives. These two developments came together in much of the debate surrounding the

\footnotetext{
* Bronwyn Strydom completed a DPhil at the University of Pretoria in 2013 with a thesis entitled, "Broad South Africanism and Higher Education: the Transvaal University College (1908 - 1919)". This article formed part of a post-doctoral fellowship in the Department of Historical and Heritage Studies at the University of Pretoria. bstrydom@gmail.com
} 
form and functions of universities in the country. The bringing together of students in places of higher learning, was seen by many as a primary means of buttressing white South African nationhood and culture.

Broad South Africanism has been regarded as a somewhat overlooked aspect of white identity politics in the twentieth century, largely due to the predominance of Afrikaner nationalist narratives and concerns. South African history scholar, Saul Dubow feels that in contrast to the causes, motives and outcomes of the South African War, "one of the major themes of this period - the ideological construction of white 'South Africanism' - has been pushed to the margins, and the effusion of political and cultural activities associated with the creative imagining of the first 'New South Africa' has been overlooked, or mentioned only in passing". ${ }^{1}$ He feels that even though the version of white nationalism, which was actively promoted among various groups in the post-War period, "eventually lost out to the more exclusivist claims of Afrikaner ethnic nationalism ... this should not obscure its historic importance or interest". He thus makes a call for scholars to devote "sufficient attention to the complex field of cultural politics that helped to bring about Union". ${ }^{2}$ This sentiment matches historian Andrew Thompson's observation that "[a]n overarching focus on what we call 'identity politics' is currently helping to revive a dialogue between South African and Commonwealth Imperial historiographies", 3 thus demonstrating the value of examining white South African identity during this interesting and unsettled period of the South African past. Broad South Africanism has been considered in relation to artistic production and its philosophical underpinnings and manifestation in public discourse have also been examined. ${ }^{4}$ This article, however, considers how this notion of white identity was related to the debate on

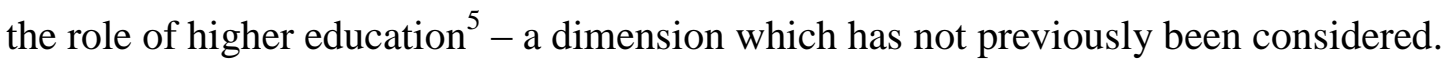

\footnotetext{
${ }^{1}$ S. Dubow, 'Imagining the New South Africa in the era of reconstruction', in D. Omissi and A. Thompson, eds, The impact of the South African War, (New York: Palgrave, 2002), 76.

${ }^{2}$ Dubow, 'Imagining the New South Africa in the era of reconstruction', 76.

${ }^{3}$ A. Thompson, 'The languages of loyalism in Southern Africa, c.1870-1939', Oxford Historical Review, cvviii, 477 (June 2003), 618.

${ }^{4}$ See Dubow, 'Imagining the New South Africa in the era of reconstruction'; S. Dubow, 'Colonial nationalism, the Milner Kindergarten and the rise of 'South Africanism', 1902-1910', History Workshop, 43 (1997), 53-85 and J. Foster, Washed in sun. Landscape and the making of white South Africa, (Pittsburgh: University of Pittsburgh Press, 2008).

${ }^{5}$ The ideological struggle over primary and secondary education during this period particularly related to language medium has received more attention from scholars than higher educational matters. This is partly due to the larger impact of primary education numerically and geographically.
} 


\section{Origins of broad South Africanism}

At the turn of the twentieth century race - or an ethnic solidarity ${ }^{6}$ which transacted class divisions - was becoming a more powerful marker of identity which further fuelled a quest for white unity. ${ }^{7}$ The bolstering of white South Africa was also promoted, among other reasons, by the desire to effectively manage its black inhabitants and also control the flow of much needed cheap labour for particularly the country's mining industry, the backbone of its economy. This background unashamedly provided momentum for the movement towards a unified white nation and political Union. ${ }^{8}$ The quest for white unity can also be viewed as a means of strengthening white position in Southern African which is in line with late nineteenth century strengthening of white supremacy and social separation between different racial groups. Scholars have shown an increase in social segregation which endeavoured to promote and maintain white class dominance from the end of the nineteenth century. ${ }^{9}$ In the wake of the mineral revolution, whiteness became increasingly linked with social and political supremacy. ${ }^{10}$

This concept of a unified white identity was promoted by an English intelligentsia and by liberal Afrikaners of the Afrikaner Bond and Het Volk persuasions. It was actively promoted by both British and local policy makers in government and public voices throughout the first three decades of the twentieth century until it was submerged by a more robust Afrikaner nationalist discourse. It's zenith can be regarded as the formation of the Union of South Africa in $1910^{11}$, although others argue that it enjoyed its greatest currency in the $1920 \mathrm{~s}$. Nonetheless Dubow proposes that "it was only after 1948 that the spirit of 'broad' South Africanism was finally dislodged as the dominant force in white politics." 12

\footnotetext{
${ }^{6}$ For definitions and a more detailed discussion of the relationship between ethnicity and group identity see $\mathrm{V}$. Bickford-Smith, Ethnic pride and racial prejudice in Victorian Cape Town (Johannesburg: Witwatersrand University Press, 1995), 2-4. Group identities can also be viewed as social constructs which develop with changing circumstances and needs. See B. Anderson, Imagined communities: reflections on the origin and spread of nationalism, (London: Verso, 1991).

${ }^{7}$ See V. Bickford-Smith, Ethnic pride and racial prejudice in Victorian Cape Town, (Johannesburg: Witwatersrand University Press, 1995).

${ }^{8}$ J. Lambert, 'South African British? Or Dominion South Africans? The evolution of an identity in the 1910s and 1920s', South African Historical Journal, 43 (November 2000), 200; Dubow, 'Imagining the New South Africa in the era of reconstruction', 81.

${ }^{9}$ V. Bickford-Smith, 'A 'special tradition of multi-racialism'? Segregation in Cape Town in the late nineteenth and early twentieth centuries', in W.G. James and M. Simons, eds, The Angry Divide. Social and economic history of the Western Cape, (Cape Town: David Philip, 1989), 47-62.

${ }^{10}$ Bickford-Smith, 'A 'special tradition of multi-racialism'?', 47 \& 61.

${ }^{11}$ Dubow, 'Imagining the New South Africa in the era of reconstruction' 78.

${ }^{12}$ Dubow, 'Imagining the New South Africa in the era of reconstruction', 92.
} 
The notion of an inclusive white South African national identity can be traced to Cape liberal politics before the South African war. In the wake of this War, endeavours to promote a new South African white identity are evident among both South Africans of British descent and Afrikaners. Members of Milner's so-called "Kindergarten” actively promoted a new form of white identity known as "broad South Africanism" among English-speaking South Africans, which included patriotic sentiment towards South Africa and loyalty to the Empire. ${ }^{13}$ Proponents of broad South Africanism encouraged white South Africans to lay aside their racial ${ }^{14}$ discrepancies and build a unified South African patriotism based on mutual interests. $^{15}$

Broad South Africanism found a parallel in the Het Volk party's policy of conciliation under Louis Botha and Jan Smuts. From its founding in 1904 the party advanced the principle of forgiving and forgetting, with the primary aim of cooperation between whites of every background in the Transvaal. Conciliation aimed at the ending of bitterness within and between white groupings while also encompassing a broader view of conciliation in South Africa as a whole, with the ultimate goal of political union, and promoted a version of loyalty to the British Empire. ${ }^{16}$

\section{Higher education and white unity at the end of the nineteenth century}

As far as higher education was concerned, at the turn of the twentieth century matters were as follows: teaching was carried out in university colleges in various centres to prepare students for the examinations of the University of the Cape of Good Hope. The university itself did

\footnotetext{
${ }^{13}$ For discussions regarding broad South Africanism and notions of loyalty to the British Empire see, Dubow, 'Imagining the New South Africa in the era of reconstruction', 76-95; Thompson, 'The languages of loyalism in Southern Africa, c.1870-1939', 617-650; S. Dubow, 'Colonial nationalism, the Milner Kindergarten and the rise of 'South Africanism', 1902-1910', History Workshop, 43 (1997), 53-85; Foster, Washed in sun. Landscape and the making of white South Africa.

${ }^{14}$ In the early twentieth century, white South Africans were viewed as two white 'races' - those from a British background who were generally English speakers and those who spoke Dutch and were referred to as Boers and later as Afrikaners.

${ }^{15}$ Dubow, 'Colonial nationalism', 57, 63 \& 67-68; M. Wilson and L. Thompson, eds, The Oxford history of South Africa II, (Oxford: Oxford University Press, 1971), 346; N. Bromberger, 'General Botha and the conciliation policy', (BA Hons essay, University of Cape Town, Cape Town, 1957), 57; Dubow, 'Imagining the New South Africa', 84-85; L.M. Thompson, The unification of South Africa, 1902-1910, (Oxford: Oxford University Press, 1960), 64.

${ }^{16}$ Bromberger, 'General Botha and the conciliation policy', 10-13; G.H.L. Le May, The Afrikaners. An historical interpretation, (Oxford \& Cambridge: Blackwell Publishers Inc., 1995), 144; H. Giliomee, The Afrikaners. Biography of a people, (Cape Town: Tafelberg, 2009), 268; F.C. Symington, 'Onderwys in die Transvaal gedurende die Kroonkolonie-periode', (DEd thesis, University of Pretoria, Pretoria, 1948), 333; Bromberger, 'General Botha and the conciliation policy', 11; Wilson and Thompson, eds, The Oxford history of South Africa, 341; Thompson, The unification of South Africa, 30-31.
} 
not undertake any teaching and was merely an examining body. This state of affairs caused much frustration and the university question was a point of debate nationally during the early part of the century in order to arrive at a better solution. This solution was generally viewed as the establishment of a teaching university for the region. ${ }^{17}$ At this stage, the extension and development of higher education was with the white population in view to train up a white elite and, although not legally enforced at this time, most university colleges primarily enrolled white students. This era did, however, also see the establishment of the first university college for black students, the South African Native College, at Fort Hare in $1916 .^{18}$

A primary means for many of buttressing white South African nationhood and culture in the early twentieth century was higher education. While education in general was prized as a means of building national identity, this aspect of the perceived function of universities has generally been glossed over in the history of South African higher education. Students enrolled at university colleges represented the future leaders, both in government and industry, of the newly united South Africa. In a sphere that reached the future elite and policy makers of the country, the potential influence is significant. Higher education in this sense represented a means to unify the dominant political and economic class. Higher education also reached the future educators of the youth - in fact those preparing to become teachers made up a large proportion of the student body - thus solidifying the nation building aspect of education in general. In fact, there is evidence of the view at this time that the primary objective of all education for a state was citizenship and thereafter vocational training or research. ${ }^{19}$ As far as can be ascertained, the first memorable evidence of this view of higher education in South Africa was a speech given by Cecil John Rhodes at an Afrikaner Bond

\footnotetext{
${ }^{17}$ E.H. Brookes, A history of the University of Natal, (Pietermaritzburg: University of Natal Press, 1966), 1; H. Phillips, The University of Cape Town, 1918-1948, ((Cape Town: University of Cape Town Press, 1993), 1; J. Edgar, 'Union and the university question and the case for a national university', reprinted from The State, April and July 1910, 1; M. Boucher, The University of the Cape of Good Hope and the University of South Africa, 1873-1946. A study in national and imperial perspective, Archives Yearbook, $35^{\text {th }}$ year, 1972, (Pretoria: Government Printer, 1974), 105; F.C. Metrowich, The development of higher education in South Africa, 18731927, (Cape Town: Maskew Miller Ltd, 1928), 36-37.

${ }^{18}$ A. Kerr, Fort Hare, 1915-1948. The evolution of an African College, (London: C. Hurst \& co, 1968); H.R. Burrows, A. Kerr and Z.K. Matthews, A short pictorial history of the University College of Fort Hare, 1916 1959, (Lovedale: Lovedale Press, 1961).

${ }^{19}$ T.J. Haarhof and R.F. Currey, "Education and research", in E.H. Brookes et al, Coming of age. Studies in South African citizenship and politics, (Cape Town: Maskew Miller Ltd, 1930), 396.
} 
congress in 1891 in Kimberley. ${ }^{20}$ Rhodes spoke of his intention to found a residential teaching university in Cape Town explaining his motives in the following way:

I saw at Bloemfontein the immense feeling of friendship that all the members had for the Grey Institute, where they had been educated and from which they had gone out to the world. It was the pleasantest dinner I had there, and I said to myself that If [sic] we could get a teaching university founded in the Cape Colony, taking the young people from Bloemfontein, Pretoria, Natal, ... they would go back to the Free State, to the Transvaal, and to Natal-let me even say they will go back to Mashonaland - tied to one another by the strongest feelings which can be created, because the period of your life when you indulge in friendships which are seldom broken is from the age of 18 to 21 . Therefore, if we had a teaching, residential university, these young men would go forth into all parts of South Africa prepared to make the future of the country, and in their hands the great question of Union could safely be left. ... I feel that should a teaching university such as I have indicated be established the young men who attend it will make the Union of South Africa in the future. Nothing will overcome the associations and the aspirations they will form under the shadow of Table Mountain. ${ }^{21}$

But there were many obstacles to Rhodes' plan, including those who felt such a teaching university would damage the position of local colleges. It is significant that this earliest attempt to create a single South African university also met with opposition precisely because of the cross cultural contact between students which it implied. For example, representatives from the Victoria College voiced objections at a meeting to discuss the plan. One Dutch Reformed minister said "that he feared the association of the Dutch students with the Rooineks - or Englishmen - on moral grounds!" 22 In spite of local rivalries, Rhodes was confident his scheme would succeed. But the Jameson Raid and impending War put university plans on hold and then Rhodes passed away in 1902. His disillusionment in the scheme can be seen in his not leaving a bequest for setting up such a teaching university, but in his leaving his money rather in the Rhodes Scholarship scheme. ${ }^{23}$

Parallel to aspirations regarding the unifying possibilities of higher education, in the period prior to the South African War there were also already signs of the disunity which would follow later. The key issue was the one that would eventually also become the dividing point, that is, language. The question of language medium in all spheres of education ran hand in hand with national aspirations throughout the period, whether inclusive or exclusive. Already

\footnotetext{
${ }^{20}$ Metrowich, The development of higher education in South Africa, 24-25.

${ }^{21}$ Quoted in Edgar, 'Union and the university question', 19.

${ }^{22}$ Quoted in Edgar, 'Union and the university question', 19.

${ }^{23}$ Metrowich, The development of higher education in South Africa, 25.
} 
in the 1890s, there were demands for the use of Dutch in University of the Cape of Good Hope (UCGH) examinations. Boucher explains that, "If the university persisted in ignoring the weight of evidence in favour of Dutch, the result might well be a strengthening of separatist tendencies in the Colony, a boost for the Taalbond which Merriman disliked so much and even desires for two universities divided on the issues of language and race." ${ }^{24}$ In the Zuid-Afrikaansche Republiek (ZAR) at this time attempts were made to provide higher education apart from the Cape and ties were rather forged with the Netherlands to assist students in receiving such an education. ${ }^{25}$

During the South African War, the hope that a university would contribute to nation building persevered. Vice-Chancellor Sir John Buchanan of the UCGH pointed to this object in his graduation day speech in 1902. The carrying on of the work of the university during the conflict was explained as an opportunity "to dispel the mists of prejudice, born of ignorance, which prevent the growth of the feeling of mutual respect, the precursor of mutual cooperation". 26

\section{Education in the Crown Colony period}

With the end of the South African War, the stress of the reconstruction era under High Commissioner for South Africa and Governor of the Transvaal and Orange River Colony, Lord Milner, was "the moulding of conquered territories along British lines". ${ }^{27}$ Certainly, Milner's ideas can be linked to "the increasingly pervasive ideology of social imperialism", ${ }^{28}$ a major part of which was the belief in British racial superiority and in their destiny to be world rulers. ${ }^{29}$ Milner's attempts to forge white unity for the sake of British supremacy bore an autocratic and intolerant flavour and consisted mainly of outnumbering and denationalising Afrikaners. ${ }^{30}$

\footnotetext{
${ }^{24}$ Boucher, The University of the Cape of Good Hope and the University of South Africa, 94.

${ }^{25}$ Boucher, The University of the Cape of Good Hope and the University of South Africa, 92-94.

26 'Vice-Chancellor Buchanan, Degree Day', The Cape Argus, 15 February 1902, quoted in Boucher, The University of the Cape of Good Hope and the University of South Africa, 96.

${ }^{27}$ Boucher, The University of the Cape of Good Hope and the University of South Africa, 99.

${ }^{28}$ S. Marks and S. Trapido, 'Lord Milner and the South African state', History Workshop, 8 (Autumn 1979), 55.

${ }^{29}$ S. Marks and S. Trapido, 'The politics of race, class and nationalism', in S. Marks and S. Trapido, eds, The politics of race, class and nationalism in twentieth-century South Africa, (New York: Longman, 1987), 2-3 \& 7; Dubow, 'Colonial nationalism', 56; Lambert, 'South African British? Or Dominion South Africans?', 204.

${ }^{30}$ Wilson and Thompson, eds, The Oxford history of South Africa, 330-333; Giliomee, The Afrikaners, 265; G.H.L. Le May, British supremacy in South Africa, 1899-1907, (Oxford: Oxford University Press, 1965$), 175$.
} 
For the British administration, education was a means to produce loyal British subjects. Thus, it was important that all sectors of the white population would be brought together in schools and educational institutions where they could be tempered and moulded in their impressionable years. Two main factors were needed to accomplish this task, namely the English language must be preeminent in education and higher education more particularly, ${ }^{31}$ and British teachers were needed to impart British character. On the first question, the British women's society, the Transvaal Women's Educational Union, reporting on the educational needs of the Transvaal Colony in 1901 stated that "[i]t is of considerable importance, politically, that the use of any language but English should die out in the Transvaal; it is also of political importance that it should die out without friction". ${ }^{32}$ Milner and his sympathisers' view of white national unity was without doubt an Anglophone one and in his view a single language - English - would be a means of erasing differences among whites. On the second question, Director of Education E.B. Sargant also explained the need of British teachers as follows: "One of my principal aims it to secure the services of men winning over the young generation of Dutch Africander to English ways of thought and speech, and English ideas of truthfulness and loyalty." ${ }^{, 33}$ For this, mining magnate Abe Bailey told Milner, the need was for "teachers imbued with British ideas and ... British instincts". ${ }^{34}$

Sargant shared Milner's enthusiasm for imperialism. He was instrumental in importing British teachers and also believed that English should be the sole medium of education, as in his view, it would inevitably become the sole language of the country. ${ }^{35}$ Milner himself also promoted this view and pointed to the importance of education in the anglicising mission in the following significant statement,

Next to the composition of the population, the thing which matters most is its education ... In the new Colonies the case will be easier to deal with, provided we make English THE LANGUAGE OF ALL HIGHER EDUCATION. ${ }^{36}$

\footnotetext{
${ }^{31}$ Boucher, The University of the Cape of Good Hope and the University of South Africa, 99.

32 'Report on the educational needs of the Transvaal Colony-1901', quoted in M.A. Basson, Die Britse invloed in die Transvaalse onderwys, Archives Yearbook 19 ${ }^{\text {th }}$ year, 1956, II, (Pretoria: Government Printer, 1956$), 177$. ${ }_{33}$ Quoted in Basson, Die Britse invloed in die Transvaalse onderwys, 159.

${ }^{34}$ Quoted in Boucher, The University of the Cape of Good Hope and the University of South Africa, 99. Emphasis is Bailey's.

35 'Sargant, Edmund Beale', in W.J. de Kock and D.W. Kruger, eds, Dictionary of South African Biography I, (Cape Town: Tafelberg, 1968), 685-686.

${ }^{36}$ Quoted in Basson, Die Britse invloed in die Transvaalse onderwys, 146. Capitalisation is in the original. Higher education at this time was used to refer to all teaching beyond primary school.
} 
This idea of higher education as a means of bridging divides between the diverse white population of the Transvaal who had recently been at war with each other, is one that occurs throughout this period in the correspondence and discussions related to education. For example, in a letter to the editor of The Star, T.C. Ward states, "It will, therefore, depend more on education than on anything else to unite South Africa and overcome the feeling of race hatred, which I think exists more on the part of the irreconcilables in Europe than amongst the farmers of South Africa". ${ }^{37}$ Another example is the Governor of the Transvaal, Lord Selborne's insistence in 1905 that at least half of the students attending the Pretoria Normal College should be British in order for "friendships of a lifetime to be formed between Boer and Briton". ${ }^{38}$ The Normal Colleges were seen as key in the project of promoting white unity as Sargant felt that "in the Normal Schools lay the best chance of educating the young teachers to a sense of their national duty and of obliterating racial prejudice". 39

The 1903 Report of the Technical Education Commission also highlighted the belief in higher education as a place of conciliation. This motivated the recommendations of the Commission regarding a centralised educational site and also informed their argument for the establishment of an agricultural school. The report states,

[t]hat in view of the large proportion of the population engaged in agricultural pursuits we consider this school is of hardly less importance to the future wellbeing of the country than a School of Mines... . Should these two schools be placed side by side, as we suggest, that intercourse amongst those representing the two foremost classes of the population, which is essential to the future settlement of the country, will be ensured at the impressionable stage of a young man's career, when lasting friendships are most readily formed. ${ }^{40}$

Evidently such an arrangement would reach those representing an elite class of both the agricultural and industrial worlds and potentially influence the future leaders and policy makers in both. Britons, however, cast doubt on the wisdom of the overtly anglicising mission of the administrators of the Transvaal Colony, seeing instead its potential to backfire. For example, when Ramsay MacDonald, who would later become British Prime Minister, visited the Transvaal after the South African War he observed, "I can only see an attempt to

\footnotetext{
37 'The education question', The Star, 12 September 1903.

${ }^{38}$ Transvaal Archives Depot (hereafter TAB), Archives of the Governor of the Transvaal Colony (hereafter GOV) 854, Selborne to Colonial Secretary, 27 November 1905.

${ }^{39}$ Quoted in Basson, Die Britse invloed in die Transvaalse onderwys, 163.

${ }^{40}$ TAB, Transvaal Publications (hereafter TKP) 193, Report of the Technical Education Commission, 1903, (Pretoria: Government Printing and Stationery Works, 1903), 8.
} 
educate Dutchmen into Englishmen end in disaster, voluntary schools, and a continuation of embittered race antagonism". ${ }^{4}$

\section{Conciliation in education in the responsible government period}

In the period of responsible government under the Het Volk party in the Transvaal, Jan Smuts was not only appointed Colonial Secretary but also Minister of Education. Furthermore, Smuts was a strong proponent of the Het Volk policy of conciliation and also a firm believer in education as a means to unite the white population. ${ }^{42}$ This accorded with the Milner drive to unite the white population through education, but did not obviously include the anglicisation process. In fact, in this period equal language rights for English and Dutch became synonymous with a united white identity.

In 1907 Smuts framed his educational policy for the Transvaal Colony in a significant speech given at the opening of a school in Boksburg. This policy bore similarities to that of Milner's in that it also envisaged the bringing together of Dutch and English-speaking children in schools with a view to promoting unity. ${ }^{43} \mathrm{He}$ explained that,

Their children would sit on the benches together, English, Dutch, Jew and German, no matter what their nationality or origin, they would sit together, be playmates together, think together and in that way they would be able to build the surest and best foundation of a happy race for the future. ${ }^{44}$

This policy corresponded with Smuts's philosophy of Holism as it was an attempt to form and cater for the "whole" in the Transvaal. It was embodied formally in the 1907 Education Act which envisaged the merging of both systems of education which had grown up in the Transvaal, namely the CNO schools and the British system. In this regard it has been described as "a positive and fundamental contribution towards the development of that 'een natie' that Smuts and Botha spoke so much about". ${ }^{4}$

The English press in the form of the Transvaal Leader signaled their approbation of his stance, writing that,

\footnotetext{
${ }^{41}$ Quoted in Basson, Die Britse invloed in die Transvaalse onderwys, 147.

${ }^{42}$ W.K. Hancock, Smuts. The sanguine years, 1870-1919, (Cambridge: Cambridge University Press, 1962), 232;

'Education. Colonial Secretary's views', Rand Daily Mail, 27 March 1907.

${ }^{43}$ Basson, Die Britse invloed in die Transvaalse onderwys, 248.

44 'Education. Colonial Secretary's views', Rand Daily Mail, 27 March 1907.

${ }^{45}$ Bromberger, 'General Botha and the conciliation policy', 52.
} 
Mr Smuts, with the eye of a true statesman, sees clearly enough that the question of race will be settled within a measurable distance of time in the schools. This is the way of unity, the way of amity, the way of comradeship and peace. Friendly emulation in the schools, whether in the class or the playground, makes for the permanent pacification of the Colony and the end of embittered division and intolerance. $^{46}$

The most significant part of the Act was the language provisions: mother tongue instruction was provided for in the lower standards, thereafter English became the medium. Dutch was allowed as a medium in a maximum of two subjects. English became a compulsory subject, while Dutch was optional. The Act caused discord among Afrikaners, but was received with relief and approval among English-speakers. What is important is that the language concessions show Smuts's attempts at a balanced conciliation in practice. ${ }^{47}$ The gravest disappointment to Afrikaners was that Smuts's policy gave up the principle of language equality. Smuts's unwillingness to defend the Afrikaans language has also been viewed, like conciliation, as the natural conclusion of his philosophy of Holism in which the Afrikaner nation was a small part of the whole. This philosophical standpoint has come under fire for promoting British influence in education in the Transvaal. ${ }^{48}$

Smuts also viewed higher education in the light of conciliation. Speaking in 1937 at UCT he also advanced the ideals of broadmindedness and co-operation. He stated,

In this country especially are we called upon to practice the larger faith and follow the larger vision. In this South Africa of ours, there is a variety of race, colour, language, religion, tradition and civilization which calls for real generosity of outlook, breadth of view and sweep of statesmanship. Only in this way can our differences be woven together into a common pattern, which will in future give South Africa distinctive character among the countries of the world. More than perhaps any other country in the world South Africa is a great human laboratory, where experiments in racial co-operation are essential to our future success. We are not without light and guidance in this enterprise. The progressive history of the human race, the testimony of great reformers, the march of ideas towards the liberation of mankind from its primitive fears and taboos, our religion and the traditions of the stocks from which we spring - all these point to the path of goodwill, sympathetic understanding and tolerance as the real line of advance for us. This is the higher wisdom of our race.

\footnotetext{
${ }^{46}$ TAB, Smuts Collection (hereafter A1) Newspaper Cuttings, volume 6, 'An Enlightened Policy’, Transvaal Leader, 28 March 1907.

${ }^{47}$ H. Giliomee, 'The beginnings of Afrikaner nationalism, 1870-1915', South African Historical Journal 19

(1987), 138; Bromberger, 'General Botha and the conciliation policy', 53-54.

${ }^{48}$ Basson, Die Britse invloed in die Transvaalse onderwys, 260.
} 
You can only be a good citizen and a patriotic South African in the measure that you show reverence for the spirit of tolerance and humanity which is the highlight of our civilization. ${ }^{49}$

In the same year, Smuts also urged this broad attitude on listeners at the University of Pretoria at the laying of the foundation stone of the Merenksy Library. He encouraged students to study modern languages and to do justice to both official languages, English and Afrikaans. ${ }^{50}$

Thus, from a brief overview of Smuts's educational policy, it is clear that he believed in the conciliatory role of both schools and universities. It is however very noteworthy, that despite these philosophical underpinnings, Smuts's influence on higher education in the Transvaal resulted in division rather than in a single unifying institution. Under the Het Volk government in 1907, Smuts doggedly and single-handedly moved the arts and science classes of the Transvaal University College in Johannesburg to Pretoria. The main criticism of his scheme was that it would divide the student population and thus not support the unifying purpose of education. In response to the proposed scheme the TUC Council reported,

This effect of the proposed organisation is to be profoundly regretted. The students will represent the future aristocracy of the professional, agricultural, and industrial sections of the inhabitants. From their ranks the leaders will be recruited. But they will not meet during their most impressionable years. They will have no opportunity to develop the mutual understanding, toleration and respect through the discipline of common fields, common class-rooms, a common hall and a common chapel. The organisation proposed will indeed fail in respect of one of the highest of university functions, namely, the cultivation of social magnanimity. The aggregate of the ablest and most cultivated members of the three fundamental sections of the inhabitants of the Colony will remain, for all that university education will do, a mixture of disparate elements, not a blend in which difference of vocation and of race are lost or at least exist but to strengthen the whole. This is the cardinal weakness of the scheme ... ${ }^{51}$

Objections voiced in the press were similar, as an article reporting on the tripartite scheme stated that the community on the Witwatersrand would certainly have misgivings about "any scheme likely to continue the separation of young students of the two sections of the

\footnotetext{
${ }^{49}$ P.B. Blanckenberg, ed, The thoughts of General Smuts, (Cape Town and Johannesburg: Juta \&Co Ltd, 1951), 14-15.

50 'Laying of foundation stone of university library. General Smuts refers to the importance of language study', Pretoria News, 11 October 1937.

${ }^{51}$ TAB, Archives of the Transvaal Education Department (hereafter TOD) 58, File 761, Report of the committee appointed by the Colonial Secretary to Consider the Question of the Organisation of Higher Education in the Transvaal, n.d., 6-8.
} 
European population, instead of bringing them together and housing them together in their impressionable years, which is surely the obvious thing to do". 52

Smuts's division was only intended to be based on disciplines - arts and sciences in Pretoria and technical and mining subjects in Johannesburg. Although his aim was not to separate English and Afrikaans-speaking students, his reorganization of higher education in the Transvaal resulted ultimately in the establishment of two separate and distinct higher education institutions within a close proximity. In what was intended to be a temporary arrangement, practical considerations trumped higher ideals regarding conciliation. In the longer term this initial division led to a deeper divide along language lines at odds with Smuts's aspirations regarding conciliation. ${ }^{53}$ Furthermore, the question of language medium was also showing its head in the university reform debate at this time, highlighting that the one hundred percent English policy would not remain unchallenged. This matter was vital in the relationship between broad South Africanism and higher education. ${ }^{54}$

\section{Union and the search for a national teaching university}

The prospect of Union of South Africa and its eventual achievement in 1910 turned the university question into one that involved the whole country and inspired the hope of establishing a national teaching university among broad South Africanists and those who believed in conciliation alike. In fact, the university debate at this point became increasingly characterised by the expression of broad South African sentiment and aspirations.

The crux of the drive for a national teaching university was that such an institution would aid in unifying white students from both 'races', thus practically carrying out the work of AngloAfrikaner conciliation. A late 1920s study of higher education presents the prevailing belief of the time that,

...the proposed University would serve as a great nationalizing force in South Africa. Indeed, no better instrument could be devised for binding the Dutch and English races together in that bond of friendship, respect and admiration for one another, which alone would create a true South African spirit of Nationality. Moreover, students would associate together, and would thus learn to appreciate

\footnotetext{
52 'The university', The Transvaal Leader, 29 November 1907.

${ }^{53}$ For a more detailed discussion of the arrangement of higher education in the Transvaal see B.L. Strydom, 'Broad South Africanism and higher education: the Transvaal University College (1908-1919)' (DPhil thesis, University of Pretoria, Pretoria, 2013).

${ }^{54}$ Boucher, The University of the Cape of Good Hope and the University of South Africa, 105, 120-123 \& 130.
} 
that corporate spirit which was so badly lacking a feature under the existing system. $^{55}$

A 1910 argument in favour of "the gathering of all classes of students in one central university" 56 also went further than just promoting relationships between English and Dutchspeaking students, to point out the benefits of students from different faculties and fields of study mixing together. He explained, "[a]ssociation with other students with different interests cultivates tolerance and breath [sic] of view, which are the two main advantages to be derived from a university education". 57

Minister of Education F.S. Malan appointed in the first Union cabinet in 1910 was also a proponent of conciliation and broad South Africanism, a fact which informed his education policy. ${ }^{58} \mathrm{He}$ envisaged the establishment of such a national institution at Groote Schuur “... which would not only weld the races of the country into one, but also direct the thought and energies of the best sons of South Africa in the future." ${ }^{59}$ His aspirations in this regard represented a widely accepted expectation of higher education at the time. For example, in 1911 the London Times published an article on education in South Africa, also promoting the establishment of "a central residential teaching university ... an institution which will assist to break down localism and racialism". 60

The flavour of discussions regarding the role of the university at this time matched the characteristics of South Africanist endeavours. ${ }^{61}$ For instance, in a lecture by TUC professor J.H. Hertz on the role of the university, in the spirit of embracing all things South African, he praised the ZAR government for the foresight and initiative it had shown in budgeting and planning for a university in the Transvaal as early as 1889. He stated "[w]e are only

\footnotetext{
${ }^{55}$ Metrowich, The development of higher education in South Africa, 49-50.

${ }^{56}$ Edgar, 'Union and the university question', 17.

${ }^{57}$ Edgar, 'Union and the university question', 17.

${ }^{58}$ F.A. Mouton, Prophet without honour. F.S. Malan: Afrikaner, South African and Cape liberal, ((Pretoria: Protea Book House, 2011), 65-79 \&109; Boucher, The University of the Cape of Good Hope and the University of South Africa, 163.

${ }^{59}$ Cape Times, 7 November 1910, quoted in Boucher, The University of the Cape of Good Hope and the University of South Africa, 154.

${ }^{60}$ Quoted in University of the Witwatersrand (hereafter Wits) Archives, File 100: History of Mining/University Education, 'A short chronology of the university movement on the Witwatersrand'.

${ }^{61}$ For characteristics of South Africanist discourse see Dubow, 'Colonial nationalism'; Dubow, 'Imagining the New South Africa'; Lambert, 'South African British? Or Dominion South Africans?’; Thompson, 'The languages of loyalism in southern Africa'; Foster, Washed in sun.
} 
continuing in the work undertaken by the Boer Government years before the War". ${ }^{62} \mathrm{He}$ therefore linked the current Transvaal to the pre-War ZAR and highlighted the common history of Transvaal inhabitants. Furthermore, in a fine example of a conciliatory view, he gave them credit for displaying "wise educational statesmanship". 63

In presenting the need for a national teaching university in 1910, Professor J. Edgar of the South African College's discourse on the university question also bears the marks of South Africanism. He emphasizes the pressing needs in the country for training to address local needs in agriculture, mining and engineering, railways, harbours, public works, medicine and law, thus elevating local South African conditions and the need for the cultivation of specifically South African knowledge. He called for "botanical, geological and zoological departments to build up a great school of South African science". ${ }^{64}$ His lecture, published in The State, emphasized this view point that "if South Africa is to be a nation worthy of the name she must train up her own men of science in the future and collect a body of facts, through research and experiment, which will enable her to deal successfully with her own peculiar problems". ${ }^{65}$ What was needed for the new country was the building up of "a sound and liberal culture in the arts as well as in the sciences". ${ }^{66}$ Thus a national university would not only bring together and promote the unity of white students, but also furnish the cultural material for a new South African nationalism. ${ }^{67}$

Despite the optimism and the widespread advancement of the nationalising benefits of a national teaching university at this time, Edgar's lecture also gives some hints of the seeds of division in the sphere of South African higher education. He explains the need of a single teaching university in order to prevent "the twin evils of racialism and provincialism" which had dogged South African education. He continues almost prophetically:

If the present system is continued these evils will remain and will become exaggerated. There will be a Dutch college and there will be an English college, and the two races will never have the chance of coming together and being educated together. A central university where all met on equal terms and associated together in a common work would promote solidarity in the nation and

\footnotetext{
${ }^{62}$ J.H. Hertz, The place of the university in modern life, (Johanneburg: R.G. McKowen \& Co, 1906), 46.

${ }^{63}$ Hertz, The place of the university in modern life, 47.

${ }^{64}$ Edgar, 'Union and the university question', 1.

${ }^{65}$ Edgar, 'Union and the university question', 11.

${ }^{66}$ Edgar, 'Union and the university question', 1.

${ }^{67}$ This is much like the notion of bildung which found expression in German universities in the late nineteenth century. See B. Wittrock, 'The modern university: three transformations', in S. Rothblatt and B. Wittrock, eds, The European and American university since 1800, (Cambridge: Cambridge University Press, 1993), 317-319.
} 
tend to obliterate racial and provincial divisions. All would feel themselves to be working together for the common good of the country and not merely in the interests of a district or of a class. And the educational advantages would be equally great. If there is to be a Dutch system of education and an English system existing side by side, as will be inevitable if the Dutch all flock to one centre and the English to another, the two sections of students will never be able to stand on a common footing in after life or be able to work harmoniously together. They will be inspired by different ideals and trained in different methods, and their energies will be wasted in fighting each other instead of being spent in cooperating together for the development of the country. ${ }^{68}$

The fact that not everyone would be brought around to appreciate the unifying benefits of a national university can be seen in the not always tactful opposition of the Victoria College supporters towards the Groote Schuur plan for a national university. This, they felt, was an attempt to bring a foreign element into South African soil, and it was precisely the nationalising effect that Afrikaners wished to avoid. Supporters of Victoria College felt that a single teaching university would mean the end of Dutch as a medium beyond primary education. According to Boucher, "the Victoria College stood for an ideal which was cherished by many Afrikaners, unwilling, as former President Steijn put it, to sell their children for half a million pounds [referring to the Werhner-Beit bequest]." ${ }^{, 69}$ The College had come to represent the cultural interests of Afrikaners. ${ }^{70}$ Indications that support for a national teaching university was also weak from Afrikaners further afield are seen in the TUC's report regarding the proposals for the establishment of such an institution. The report warned that Dutch-speaking parents would prefer local centres for their children's education and would be wary of "the cosmopolitan atmosphere of a large national university". 71

In fact, the political situation shortly after Union showed that the dream of white unity was not to be achieved so smoothly. The split between Botha and Hertzog in 1914 further strengthened supporters of Victoria College as a Dutch-speaking centre in their endeavours to protect the college in impending university reforms. Evidently, considerations of the various role-players in solving the university question were not always merely educational. In fact, popular perceptions of some of the university colleges in the years immediately following the Union show that polarisation was already taking place in the realm of higher education at the very time when the hope of conciliators was to use higher education as a unifying force. For

\footnotetext{
${ }^{68}$ Edgar, 'Union and the university question', 18.

${ }^{69}$ Boucher, The University of the Cape of Good Hope and the University of South Africa, 164-165.

${ }^{70}$ Giliomee, The Afrikaners, 363.

${ }^{71}$ Boucher, The University of the Cape of Good Hope and the University of South Africa, 157.
} 
instance, it has been stated by English-speakers that Victoria College was viewed as a breeding ground for Hertzogism and Reactionism. On the other hand, Afrikaners felt that the School of Mines in Johannesburg was an English institution and that insufficient attention was given to Afrikaans and Dutch culture at the South African College (SAC). Generally speaking, there was also a feeling from some quarters that not enough was being done in the domain of higher education to promote the Dutch language and the national sentiments of Dutch-speakers. $^{72}$

Thus, the underlying issue which lacked resolution in all aspects of the new Union of South Africa, including university affairs, was the matter of equality between the two white races. What this meant in effect and how it would be carried out practically was uncertain. It was entrenched in the language clause of the new Union and increasingly would come to be represented by the quest for language rights in practice. ${ }^{73}$

\section{The 1916 University Acts and beyond}

The desire to carry out conciliation by means of the country's higher education was put to the test when it came to finding an actual practical solution to the university question. The eventual solution was the 1916 University Acts, which instead of creating one national teaching university, created one federal university - the University of South Africa with five constituent university colleges - and two teaching universities, the universities of Cape Town and Stellenbosch.

The Werhner-Beit bequests which gave the necessary financial impetus for the establishment of a teaching university were not only made with a view to the development of higher education in the country, but also for the advancement of a unified South African nationalism. The donors, like many others, were firmly persuaded "that nothing would weld the new nation more firmly together than that its future leaders should spend the most impressionable years of their lives in the social atmosphere of a residential university" ${ }^{74}$ The actual outcome of the university scheme in 1916, however, raised serious doubts as to whether this latter goal had been achieved. For example, in the mayor of Johannesburg's telegram to Lionel Phillips, asking him to intervene in the matter of the Beit bequest, he

\footnotetext{
${ }^{72}$ Boucher, The University of the Cape of Good Hope and the University of South Africa, 148 \& 164.

${ }^{73}$ Boucher, The University of the Cape of Good Hope and the University of South Africa, 147-148.

${ }^{74}$ T. Reunert, 'The university question and the Rand', Paper presented to the Witwatersrand Local Centre of the South African Association for the Advancement of Science, February 1916, 3.
} 
pointed out that the 1916 Acts went against the ideal of a national teaching university which would cater for both white 'races' and, by establishing two teaching universities, opened the way for universities to grow along racial lines. ${ }^{75}$

Much like the division of teaching between Johannesburg and Pretoria in 1908, the 1916 Acts showed that choices had to be made which did not always match the aspiration that higher education would bring the nation's students together. In the case of the 1908 decision, two separate and increasingly divergent institutions in terms of language, identity and ideology emerged. In 1916 a foundation for divergence on the point of language was also laid in the Cape, right at the time when promoters of university education in the country were endeavouring to establish a single national teaching institution. ${ }^{76}$ Edgar also acknowledged the difficulties which arose from "vested interests in the separate colleges, and the strength of local feeling" and concedes that there is an argument for a practical solution in contrast to what is "ideally perfect". 77

The 1916 Acts show two major obstacles to the achievement of a national and unifying university. Firstly, the social distances between different sections of white South Africans were not so easily overcome by just over a decade of attempts to unify them. The suspicion and antagonism resulting from events of the recent past, such as the South African War and Milnerism, still lingered. In the second place, the important influence of "deeply rooted" local aspirations and interests has also been pointed out. Regional sentiment was linked strongly to white identity and was even influential in expressions of loyalty. ${ }^{78}$ It also had a strong influence over the course of higher education, as cities competed to establish colleges and universities in later years.

The key issue which was at stake, however, and was beginning to become increasingly manifest was again the matter of language. In the wake of the Second Language Movement, which began in the first decade after the South African War, efforts grew to establish

\footnotetext{
${ }^{75}$ Reunert, 'The university question and the Rand', 11; P. Venter, 'Die groei van onderwysaangeleenthede in Johannesburg. 1886-1920', (DEd thesis, University of South Africa, Pretoria, 1950), 555-556.

${ }^{76}$ The University of Cape Town was an English medium institution, while the nearby University of Stellenbosch catered primarily for Dutch speakers.

${ }^{77}$ Edgar, 'Union and the university question', 19.

${ }^{78}$ Metrowich, The development of higher education in South Africa, 83; Boucher, The University of the Cape of Good Hope and the University of South Africa, 259-260; Thompson, 'The languages of loyalism in Southern Africa', 647.
} 
Afrikaans ${ }^{79}$ on equal terms with English in all spheres of life. The South African Party government under Botha after Union was inclined to let the matter of language take its course and allow for the survival of the fittest. ${ }^{80}$ Furthermore, in line with their policy of conciliation towards English-speakers, Botha and Smuts were unwilling to insist on the matter of language. In was in this matter of language that a growing Afrikaans intelligentsia would differ from the nationalism of Botha, Smuts and Het Volk. ${ }^{81}$ Especially after the split between Botha and Hertzog and the outbreak of World War I in 1914 language became increasingly "the key badge of identity". As such Foster claimed that it "posed a powerful, and in some ways unanswerable, challenge to proponents of a more inclusive colonial national (but ultimately Anglophone) construction of white nationhood." ${ }^{, 82}$

In the sphere of higher education, Dutch had finally been given recognition by the UCGH in 1910, although English remained the dominant language of higher education. In 1914 provision was made for Afrikaans to be taught in schools and in 1918 it was introduced as a subject in two university institutions. ${ }^{83}$ There were also calls for the introduction of Afrikaans by Unisa as a medium of instruction from the time of its inception in $1918 .{ }^{84}$ At this time the Minister of Education put forward the view that "the bilingual student should be regarded as the normal student". ${ }^{85}$ In a sense bilingualism can be regarded as the new symbol of broad South Africanism in higher education in the second decade of the twentieth century.

But a situation in which two mediums exist is difficult to maintain in practicality and failure to put this into practice satisfactorily led to single medium institutions which ultimately signalled divisions along ideological and other lines. The difficulties attached to upholding bilingual systems at various institutions and the increasingly ideologically charged matter of language, created a dual system of universities which went completely counter to the goal of broad South Africanism and conciliation.

\footnotetext{
${ }^{79}$ The growth of Afrikaans has been investigated by a number of historians. See for example, I. Hofmeyr, 'Building a nation from words: Afrikaans language, literature and ethnic identity, 1902-1924', in Marjs and Trapido, eds, The politics of race, class and nationalism, 95-123.

${ }^{80}$ Giliomee, The Afrikaners, 362.

${ }^{81}$ Giliomee, The Afrikaners, 358-359; Boucher, The University of the Cape of Good Hope and the University of South Africa, 143-144; Marks and Trapido, 'The politics of race, class and nationalism', 11-12 \& 17.

${ }^{82}$ Foster, Washed in sun, 32.

${ }^{83}$ Grey University College and the University of Stellenbosch.

${ }^{84}$ Hofmeyr, 'Building a nation from words', 106-107; Boucher, The University of the Cape of Good Hope and the University of South Africa, 143-144 \& 190.

${ }^{85}$ Boucher, The University of the Cape of Good Hope and the University of South Africa, 190; University of Pretoria Archives (hereafter UPA), B-5-1-1, Notules van die Senaat: 1916-1923, Appendix: Copy of circular from Under Secretary for Education, 12 June 1918, 261.
} 


\section{Nation building and higher education}

In spite of the fact that the conciliatory spirit seemed to fail to get off the ground in the South African university system, the idea that universities were a primary factor in nation building is an idea which prevailed throughout the first three decades of the twentieth century. Two significant commissions of inquiry into university matters, the Van der Horst Commission (1928) and the Adamson Commission (1933) highlight this enduring belief in the university's unifying role.

The Van der Horst Commission, which investigated the relationship between universities, university colleges and technical institutions, suggested:

that the main justification for Universities lies in the claim that they are essential safeguards in the development of communities. The organisation of groups within the community is a marked feature of modern everyday life, and the struggle between groups may endanger the very existence of our complex civilisation. The best safeguard against that danger seems to be an education which will give every member of the community an idea of the interdependence of all groups and a feeling for the interests of the whole. ... Universities are bound to have a large influence upon the formation of the national character in this respect. ${ }^{86}$

The so-called Adamson Commission, which was investigating the question of university subsidies, quoted this section from the Van der Horst Report, and expanded on it by explaining that,

by communities the Commissioners seem to have had national units in mind. They held it to be the primary function of universities to counteract the centrifugal effect of group rivalries and by affirming the interdependence of their interests to buttress the ideal of national unity. ... If we can all hold fast to the ideal of contribution rather than rivalry, then the very diversities of origin and tradition which our university institutions enshrine will be a source of strength rather than weakness. State subsidies will be justified on the highest ground of all, that of a contribution to a sane and tolerant nationality. ${ }^{87}$

According to the Van der Horst Commission, a key factor regarded as a necessity for promoting this function of the university, was the existence of a certain "atmosphere". Though intangible, this atmosphere would be present "where the number of students and teachers is sufficiently large and diversified, and where the manner of living brings them sufficiently into contact with each other." Such "contact and the resulting interchange of

\footnotetext{
${ }^{86}$ J.G. van der Horst et al, Report of the University Commission, (Pretoria, The Government Printing and Stationery Office: 1928), 16.

${ }^{87}$ J.E. Adamson, J.J.I. Middleton \& S.F.N. Gie, Report of the Committee of Enquiry into Subsidies to Universities, University Colleges and Technical Colleges, (Pretoria, The Government Printer: 1934), 5.
} 
ideas is of far greater importance in University education than the mere passing of examinations. ${ }^{\prime 88}$ For this reason, the Commission was critical of certain university colleges, like the Huguenot University College and the Potchefstroom University College, where it was felt that the limited number of students and the lack of diversity "deprive[d] them of one of the most important benefits of University life - the friction of mind upon mind". 89

The ideal of broad South Africanism was characterised by optimism in the support it enjoyed in the 1920s, particularly among English-speakers. ${ }^{90}$ This "loyalist Greater South African identity" has been described as "engagingly idealistic and pragmatically vague", 91 thus accounting for the broad support it received. Furthermore, at this time Afrikaner national sentiment was only beginning to develop and it has been stated that before 1930 there was "a more fluid relationship between language and identity, and consequently a looser definition of national identity, than that which later became associated with the country." 92 Dubow, however, has indicated that the highpoint for the spirit of conciliation in the country probably occurred somewhere between Milner's departure and the outbreak of World War I. ${ }^{93}$ A 1930 survey of the progress of the Union by a group of liberal thinkers pointed to some disappointment and impatience at the slow progress of national unity. ${ }^{94}$ In the end, the more robust national identity fostered by Afrikaners would come to wear down this imagined sense of white unity. ${ }^{95}$

\section{Conclusion}

Historically, the matter of universities in South Africa was strongly linked to endeavours to build white unity and a new South African nationalism even prior to the South African War. In the first few decades of the twentieth century this notion regarding higher education developed further in the hope that the bringing together of students in universities would help to eradicate the antagonisms surrounding the South African War and British imperial activity in the region. The development of higher education and its perceived function was very much wrapped up with this pursuit of a new South Africanism and among broad South Africanists

\footnotetext{
${ }^{88}$ Van der Horst et al., Report of the University Commission, 16.

${ }^{89}$ Van der Horst et al., Report of the University Commission, 17.

90 Thompson, 'The languages of loyalism in Southern Africa', 644-645.

${ }^{91}$ Foster, Washed in sun, 30.

${ }^{92}$ Foster, Washed in sun, 30.

${ }^{93}$ Dubow, 'Imagining the New South Africa in the era of reconstruction', 78.

94 J.H. Hofmeyr, 'Introduction', in Brookes et al, Coming of age, 1 \& 5.

95 Thompson, 'The languages of loyalism in Southern Africa', 649; Foster, Washed in sun, 29.
} 
and conciliators its potential nationalising influence was highly prized. The expression of broad South African sentiment, on the one hand, can be traced as a main feature of the university reform debate. On the other hand, a parallel line of exclusive national feeling also can be found which favoured universities which would endeavour to preserve and build up more unique cultural and national interests. These two lines formed part of the early years of many higher education institutions around the country and the predominance of one over the other ultimately formed the character of a number of South African universities in the twentieth century. 